\title{
ESTIMATED UNRECORDED CATCH RELATED TO THE NUMBER OF LICENSED FISHING VESSEL IN THE ARAFURA SEA
}

\author{
Badrudin'), Subhat Nurhakim ${ }^{2)}$, and Budi Iskandar Prisantoso ${ }^{2)}$ \\ 1) Research Institute for Marine Fisheries, Muara Baru-Jakarta \\ 2) Research Center for Capture Fisheries, Ancol-Jakarta \\ Received June 13-2008; Received in revised form July 1-2008; Accepted July 10-200
}

\begin{abstract}
The fish resources in the Arafura Sea have been intensively exploited by the industrial scale of fish trawl (fish net), shrimp net and bottom long line. From experience worldwide it has been shown that excessive number of licensed fishing vessel engaged in fisheries will suffer from over-capitalization and falling productivity and will lead to the brink of biological collapse. Excessive number of licensed fishing vessel has resulted to the occurrence of unrecorded catch, that can be interpreted as one of the illegal, unreported, and unregulated fishing activities. Based on the estimated total catch of 1043,500 tonnes in 2000 and is regarded as an anchor point and by applying a constant raising factor, the annual catch in the period of 1997 until 2004 has been estimated. The average annual loss in the form of unrecorded catches during 1997 until 2004 was about 711,137 tonnes. If the average fish price during this periode was US \$ 1 per $\mathrm{kg}$, the total annual losses to Indonesia was about US $\$ 711,137,000$ per year (US $\$ 711,1$ million). These catch estimation was originated only from the industrial scale of fish trawl, shrimp trawl and bottom.long line. The catch from oceanic gill net, coastal gill net, squid jigs, bouke ami, and traps was not included. By applying the surplus production model the position of maximum yield and optimum number of fishing vessel can be determined. From these figure, it was likely that the status of fish resources exploitation in the Arafura Sea has been fully exploited.
\end{abstract}

KEYWORDS: $\quad$ unrecorded catch, number of licensed fishing vessel, exploitation status, Arafura Sea

\section{INTRODUCTION}

From experience worldwide it has been shown that excessive number of licensed fishing vessel engaged in fisheries generally suffer from over-capitalization and falling productivity and, with increasing frequency, this fishery will face the threat of biological collapse. These problems arise because of the lack of exclusive individual rights over the fish resources. The essence of the problem is that the actions of individual fisher create cost for other fishers. The result of behaviour which is economically rational at the individual level provides unnecessary cost, excessive fishing effort and possible resources over exploitation. At the industry level, the result is a loss of potential profit. The objective to be pursued in the future management of the Arafura Sea fisheries should cover to ensure biological sustainability of the resource, to maximise the economic efficiency of resources use, and to ensure that private users of a community resource provide an appropriate return to the community for the right to exploit that resource for private gain. If the objectives are met, a stable economic and biological environment will be established in which fishers can pursue their commercial activities with greater confidence of a secure and viable future. In the contex of the Government Role in fisheries management, the three objective are not alternatives but are mutually reinforcing. This is an important point when understanding and determining what policies are appropriate for fisheries management.
Unrecorded catch can be interpreted as one of the illegal, unreported, and unregulated fishing activities and has become an international environmental problem during the last decade (Anonymous, 2001). The fish resources in the Arafura Sea have been intensively exploited by the industrial scale of fish trawl (fish net), shrimp net, and bottom long line. Bottom long line provides a relatively selective fishing gear usually targetted effectively on large demersal fishes. Intensive fishing activities in the Arafura Sea that has been happening during the last two three decades will lead to over exploitation as already happened in the Australian sector of the Arafura Sea. With the closing of foreign fishing licence for groundfish resources in the Australian sector of the Arafura Sea and the Timor Sea for Taiwan, Thailand, and Japan in 1990 due to the decreasing catch per unit of effort (Ramm, 1995) provides one of the evidences that growth rate of fish could not afford to balance the occurring high fishing pressures.

This paper is based on catch data of trawl fish net (catcher boat) that transshiped their catches to the fish carrier from one fishing company based in Tual, shrimp trawlers of HPPI member, and the Tanjung Balai Karimun-Riau bottom long line with the sub bases in Probolinggo and Kupang. The result is expected to represent basic informations that can be used for the estimation of the actual total fish catches, the unrecorded catch, the optimum number of licenced 
fishing vessel and the expioitation level of fish resources in the Arafura Sea.

\section{MATERIALS AND METHODS}

The statistics and primary data were used in the analyses. The fisheries statistical data cover fish landing and the total number of $>30$ GT licensed fishing vessel in the Arafura Sea Fisheries ManagementArea during the period 1997 to 2004 , regardless their fishing gears used. The primary catch data were obtained from the industrial scale of fish trawl (fish net), shrimp trawl and bottom long line, and was regarded as an anchor point. Fish trawl data was obtained in the form of catch from catcher boat that transshipped into fish carrier of the Tual based fishing company carried out in 2000 . Those data originated from 144 catcher boats that transshipped into 16 fish carriers (Badrudin et al., 2004). Total catch estimation of the fish trawlers was based on catch per vessel per trip multiflied by the total number of licensed fish trawlers. The catch data of the fish trawlers was presented in the form of catch list of fish species or species group in English and Thai scripts, while the common name of the fish on the list was checked according. Shrimp catch data analyzed originated from 1,033 shrimp trawlers during the period of 1991 to 2002 reported by Hernowo (2003). Total catch estimation of the shrimp trawlers based on the catch per vessel per year with the proportion of shrimp and fish caught was 1:12 (Badrudin, 2007). Differing with trawl fish net and shrimp trawler where the data used was on annual basis, the bottom long line catch per unit of effort was based on catch data of the six unit bottom long line carried out fishing in 69 effective fishing days during 2000, 2001, and 2002 (Badrudin et al., 2004a). With the assumption that the unit of bottom long line operated in 200 days per year and their catchability for each unit is equal, by multiplying the catch per unit of effort with the number of bottom long line fishing vessel, the total catch can be calculated.

Based on the primary data, the estimated total catch from the three industrial scale of fisheries in 2000 was regarded as an anchor point. By applying a constant raising factor, the estimated annual catch in the period of 1997 to 2004 can be calculated, together with the weighted annual total number of fishing vessel, so that annual catch per vessel can also be calculated. By applying the surplus production model the position of maximum yield and optimum number of fishing vessel can be determined.

\section{RESULTS AND DISCUSSIONS}

\section{The Arafura Sea Fisheries}

The trawl fish net fishing activities in the Indoinesian sector of the Arafura Sea have been rapidly carried out and expanded without any appropriate control especially for the exchartered arrangement fishing vessels with the crews from their original countries (mainly Thai). Most of the catch of such vessels were unrecorded or unreported as these catches were usually transshipped and directly transported into their original countries. This situation will undoubtedly provide loss to Indonesia, either in the form of income, decreasing trend in the index of abundance or the fish landing data accuracy used in the stock assessment that the result might be misleading. Catch rate provide one of the index of abundance of fish resources. The amount of catch rate provide an indicator depicting the stock density of the available fish resources in the waters. It is obvious that the total recorded catch from 144 boats (catcher) using fish net was about 16,000 tonnes, and the catch rate of 111,2 tonnes per trip (Badrudin et al., 2004). If the total number of licensed fish net operated in the Arafura Sea at that time was 779 units (Anonymous, 2007 ), with the average of 6 trips per year per boat, the estimated total catch can be calculated.

In the shrimp trawling that have been carried out for years, a substantial amount of fish caught is considered as by catch. The proportion of shrimp and fish were varied from one fishing ground to another, usually between 5 to $20 \%$ of the total catch (Badrudin \& Karyana, 1993; Widodo, 1997; Sumiono et al., 2001; Budihardjo \& Budiman, 2003). The shrimp resources in the Indonesian sector of the Arafura Sea have been exploited for years, started from the Indonesia-Japan joint venture era (1960 th). Based on the catch data collected from the 1,033 trawl boats during the period 1991 to 2002 (Hernowo, 2003), the average catch rate of shrimp fishery was about 73.52 tonnes per boat per year, with the relatively smaller variation of only $9.3 \%$. This data implied that the shrimp exploitation in the Arafura Sea has been approaching a stabilized phase, where a significant increase in the annual catch rate could no longer be expected. With the assumption that the average proportion of shrimp and fish was 1:12 (Badrudin, 2007), the estimated fish caught by the shrimp net can be calculated. 
Catch rate data of bottom long line were obtained from the Observer Programme of the ACIAR-Indonesia collaborative research on red snappers resources in the Arafura Sea. During the 2000, 2001, and 2002 a total of 12 observers have been placed on 6 units of bottom long line fishing boat. These bottom long line fishing boats were usually targetted on the large demersal food fish, such as red snappers, groupers, emperors, and others. Catch rate (hook rate) of the bottom long line fishing boat was calculated based on data obtained from 6 units of bottom long line fishing boats. The observer joining the bottom long line fishing operation varied between 8 to 15 effective fishing days from the total of approximately two month fishing operations. The average catch rate of bottom long line fishing boat during 2000, 2001, and 2002 was about $643 \mathrm{kgs}$ per boat per day (Badrudin et al., 2004a).

\section{Total Catch Estimation}

The estimation of the total catch was based only on the number of fish trawl (fish net), shrimp trawl and bottom long line. The catches obtained by the small scale fisheries such as found in Merauke, Kaimana, Tembagapura, and other fishing villages along the southwest coast of Papua were not included. The estimated total catch in the Arafura Sea in 2000 was about 1043,500 tonnes (Table 1).

Table 1. Total catch estimation in the Arafura Sea (2000)

\begin{tabular}{|c|c|c|c|}
\hline Fisheries & No. of fishing boats & Average catch rate & Estimated total catch (tonnes) \\
\hline Fish net/Trawl & $779^{1)}$ & 111.2 tonnes per boat per trip & $519,749^{2)}$ \\
\hline Shrimp & $526^{1)}$ & 73.52 tonnes per boat per year & $502,730^{3)}$ \\
\hline Bottom long line & 169 & 643 kgs per boats per day & $21,090^{4)}$ \\
\hline \multicolumn{3}{|c|}{ Total catch } & $\begin{array}{c}1043,569 \\
(1043,500)\end{array}$ \\
\hline
\end{tabular}

Compare with the estimated total catch obtained by the fish net per trawl, shrimp net, and bottom long line of 1043,569 tonnes, the recorded catch reported in the fisheries statistics was far below the catch, which was only about $27,5 \%(286,704 / 1043,569)$. As reported by Purwanto (2003), the licensed fishing vessels operated in the Arafura Sea include oceanic and coastal gill nets, squid jigs, bouke ami, traps, tuna long line, and a number of small scale fishing gears based in Merauke, Kaimana, Tembagapura, and other fishing villages along the southwest coast of Papua. The low recorded catch in the statistics was probably due to the inappropriate data collection methodology as the unreported catch was not considered. The problems are where the most of the catches were transported, landed and recorded. The accuracy of data analysed are likely related also with the number of the real fish net (both licensed or illegal), shrimp net and bottom long line fishing boat operated in this waters, which are unkonwn. It is acknowledged that monitoring control and surveillance measures in most remote waters areas such as the Arafura Sea, South China Sea, Sulawesi Sea, and Indian Ocean, where illegal fishing has often been encountered, have not been regularly carried out.

\section{Estimated Annual Catch Period 1997 to 2004}

Based on the estimated total catch of 1043,500 tonnes in 2000 (Table 1) and regarded as anchor point compared with the recorded catch, the estimated catch in the previous year (1997 to 1999) and in the following years (2001 to 2004) can be calculated by applying a constant raising factor; where raising factor $2000=$ (anchor point: (recorded catch: number of vessel $) \rightarrow(1043,569 /(286704 / 1125))=4095$. The estimated annual catch were calculated by multiplying the raising factor with the catch per fishing vessel. So that, the catch in 1997 for example: 4095* (248471) $726)=1401500$. By applying the same procedure the estimated annual catch of 1997 to 2004 can be obtained (Table 2).

According to the official data presented by the licensing division of the Directorate General of Capture Fisheries (Anonymous, 2007), the total number of licensed fish trawl and shrimp trawl in 2000 was 1,305 units $(779+526=1,305)$, while the total recorded number of fishing vessel in 2000 was only 1,125 units (Table 2 ), or approximately $20 \%$ less. By adding up a $20 \%$ to the annual number of fishing vessel, a new estimate of the number of fishing vessel, the raising factor and the estimated catch can be obtained (Table 3).

Based on the data in Table 3, it is likely that the difference between the annual recorded catch and the estimated catch (unrecorded) was quite high. The trend of the recorded catch during 1997 to 2004 was almost horizontal while the unrecorded catch during the period 
1997 to 2004 was decreasing. The average annual loss in the form of unrecorded catches during 1997 to 2004 was about 711,137 tonnes (Table 3 ). If the average fish price during this periode was US \$ 1 per $\mathrm{kg}$, the total annual losses to Indonesia was about US $\$ 711,137,000$ per year (US $\$ 711,1$ million). These catch estimation was originated only from the industrial scale of fish trawl, shrimp trawl and bottom long line. The catch from oceanic gill net, coastal gill net, squid jigs, bouke ami, and traps was not included.

\section{Exploitation Status of Fish Resources}

From Table 3 , it is possible to relate the catch and the number of fishing vessel, where the annual catch per vessel (catch per unit of effort) within the period 1997 to 2004 can be calculated (Table 4). By applying the surplus production model, the relationship between effort $(Y)$ and catch per unit of effort $(X)$ follows the regression equation of: $Y=2902.8$ $1.5589 \times(n=8 ; r=0.985)$. From this equation, the calculated MSY $=1351313$ (1350,000 tonnes).

Table 2. Annual estimated catch based on anchor point and raising factor

\begin{tabular}{ccccc}
\hline & Recorded catch (tonnes) $\left.{ }^{*}\right)$ & Fishing vessel $>30$ GT & R.F. & Estimated Catch (tonnes) \\
\hline 1997 & 248,471 & 726 & 4,095 & $1,401,500$ \\
1998 & 268,716 & 1,032 & 4,095 & $1,066,271$ \\
1999 & 272,760 & 1,167 & 4,095 & 957,114 \\
2000 & 286,704 & 1,125 & 4,095 & $1,043,569$ \\
2001 & 249,215 & 1,232 & 4,095 & 828,357 \\
2002 & 223,683 & 1,338 & 4,095 & 684,590 \\
2003 & 294,374 & 1,237 & 4,095 & 974,504 \\
2004 & 264,157 & 1,288 & 4,095 & 839,848 \\
\hline
\end{tabular}

Remarks: *) Fisheries Statistics of the Arafura Sea Fisheries Management Area (Statistik WPP L. Arafura)

Table 3. Adjusted annual estimated number of vessel, raising factor, total catch, and unrecorded catch

\begin{tabular}{cccccc}
\hline & $\begin{array}{c}\text { Recorded } \\
\text { Catch (RC) }\end{array}$ & $\begin{array}{c}\text { Fishing vessel } \\
\text { >30 GT }\end{array}$ & R.F. & $\begin{array}{c}\text { Total } \\
\text { Catch (TC) }\end{array}$ & $\begin{array}{c}\text { Unrecorded } \\
\text { TC-RC }\end{array}$ \\
\hline 1997 & 248,471 & 871 & 4,919 & $1,402,926$ & $1,154,455$ \\
1998 & 268,716 & 1,238 & 4,914 & $1,066,271$ & 797,555 \\
1999 & 272,760 & 1,400 & 4,914 & 957,114 & 684,354 \\
2000 & 286,704 & 1,350 & 4,914 & $1,043,569$ & 756,865 \\
2001 & 249,215 & 1,478 & 4,914 & 828,357 & 579,142 \\
2002 & 223,683 & 1,606 & 4,914 & 684,590 & 460,907 \\
2003 & 294,374 & 1,484 & 4,914 & 974,504 & 680,130 \\
2004 & 264,157 & 1,546 & 4,914 & 839,848 & 575,691 \\
\hline \multicolumn{7}{c}{ Average annual lost (tonnes) } \\
\hline
\end{tabular}

Table 4. Annual catch, effort, and catch per unit of effort of fish resources in the Arafura Sea

\begin{tabular}{cccc}
\hline Years & Est. annual catch & No. Fishing vessel (effort) & Catch/vessel (CPUE) \\
\hline 1997 & $1,402,926$ & 871 & 1,930 \\
1998 & $1,066,271$ & 1,238 & 1,033 \\
1999 & 957,114 & 1,400 & 820 \\
2000 & $1,043,568$ & 1,350 & 928 \\
2001 & 828,357 & 1,478 & 672 \\
2002 & 684,590 & 1,606 & 512 \\
2003 & 974,504 & 1,484 & 788 \\
2004 & 839,848 & 1,546 & 652 \\
\hline & Regression parameter & $\mathrm{A}=2902.8$ & $\mathrm{~b}=1.5589$ \\
\hline MSY & Mean & Lower limit & Upper limit \\
\hline Fopt & $1,351,313$ & $1,151,825$ & $1,634,375$
\end{tabular}


The position of maximum yield and optimum effort are obvious (Figure 1). Compare with the licenced fishing vessel issued by the Licensing Division of the Directorate General of Capture Fisheries, it is likely that the exploitation level of fish resource in the Arafura Sea was already in the state of fully exploitation (2004). This is reflected by the ever decreasing trend of catch per vessel (catch per unit of effort) as an index of abundance. As the optimum effort of about 931 fishing vessel unit and giving the maximum yield, the position of the number of licensed fishing vessel was 1,587 units (Appendix 1). Question arise as to whether the possibility to rebuilt the stock back into the position between the 1997 and 1998 can be carried out. From this figure it is also revealed that the index of abundance of fish resources in the Arafura Sea in 2004 was only about one third left compare with those in the 1997. Management measure in the form of reducing effort is probably the only way to rehabilitate the stock.

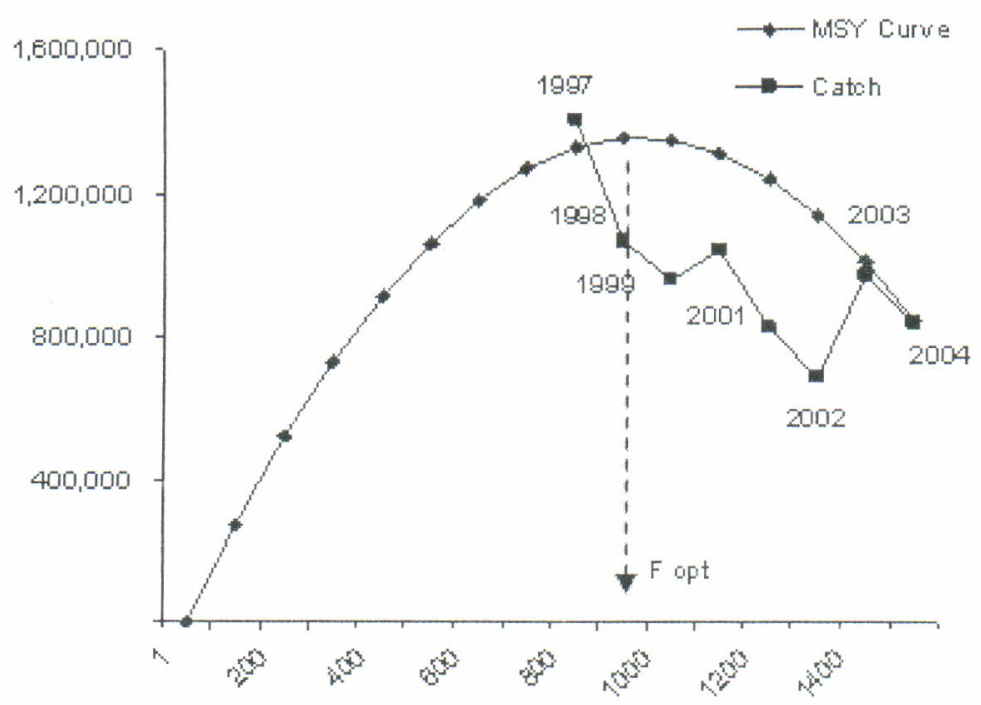

Figure 1. Position of maximum yield and optimum number of fishing vessel.

As pointed out by Larkin (1982), perhaps the most serious obstacle to effective management stems from the lack of communication between scientists, administrators, decision makers and fishers. Fishers may' not be convinced that it would be in their own long term interest to cooperate in measure to manage the resources. Administrators or decision makers are rarely influenced by the fact that too much fishing effort is an inefficient use of resources. They may be prepared to take action only if they can be convinced that a particular resource is about to collapse. Scientist do not always appreciate that socio economic factors may have to take precedence in the short term over the long term objective of attaining a maximum biological yield. It was repeatedly brought out in discussions that at present in most of the southeast Asian country there is virtually no biological basis to the management of fisheries. The necessary information is often lacking. Where it is available, it may not have been analyzed. Where it has been analyzed and presented to administrators, it may not have led to regulations. Where regulation have been imposed, they may not have been enforced. In short, there is much to be done to improve the management of Arafura Sea fisheries. To a very large extent, management of fisheries has been more concerned with reconciling conflict between different socio economic groups than with attaining long term goals, such as maximum biological yield.

\section{CONCLUSION}

1. Excessive number of licensed fishing has resulted to the occurrence of unrecorded catch. Based on the estimated total catch of 1043,500 tonnes in 2000 it is likely that the total catch in the Arafura Sea has been far exceeded the reported catch, while the following annual catch tend to be decreasing.

2. The average annual loss in the form of unrecorded catches during 1997 to 2004 was about 711,137 tonnes. If the average fish price during this periode was US $\$ 1$ per $\mathrm{kg}$, the total annual losses to Indonesia was about US $\$ 711,137,000$ per year (US \$ 711,1 million). These catch estimation was originated only from the industrial scale of fish trawl, shrimp trawl, and bottom long line. The catch 
from oceanic gill net, coastal gill net, squid jigs, bouke ami, and traps was not included.

3. By applying the surplus production model the position of maximum yield and optimum number of fishing vessel has been surpassed. From this figure, it was likely that the status of fish resources exploitation in the Arafura Sea has been fully exploited.

\section{ACKNOWEDGMENTS}

This paper is part of the research results carried out in the framework of fish stock assessment in the Arafura Sea by the Research Institute for Marine Fisheries during the F.Y. 2006 and part of the research on licensing policy analysis carried out by the Research Center for Capture Fisheries in F. Y. 2007. We would like to thank Dr. Purwito Martosubroto, Chairman of National Committee for Fish Stock Assessment for his encouragement, helpul discussion and suggestion.

\section{REFERENCES}

Anonymous. 2001. National forum on illegal, unreported, and unregulated fishing activities in Indonesian waters. CMPOCRC Univ. of Wollongong-ACIAR. Jakarta. $40 \mathrm{p}$.

Anonymous. 2007. Perizinan kapal di Laut Arafura. Direktorat Pelayanan Usaha Penangkapan Ikan. Direktorat Jenderal Perikanan Tangkap. Presentasi dalam Rangka Study on the implications of Illegal, Unreported, and Unregulated Fishing in the Arafura Sea for Indonesian Fishery Statistics. Pusat Riset Perikanan Tangkap. 23 Mei 2007. (Unpublished).

Badrudin. 2007. Results of the fisheries research in the Arafura Sea. Powerpoint presentation: A study of illegal, unreported, and unregulated fishing in the Arafura Sea, Indonesia. Jakarta. 23 Mei 2007. FAO-RCCF Collaborative Research. 13 .

Badrudin \& Karyana. 1993. Proporsi dan komposisi udang dan ikan demersal di Laut Arafura. Jurnal Penelitian Perikanan Laut. Balai Penelitian Perikanan Laut. Jakarta. No.79. 14-23.
Badrudin, S. Nurhakim, \& B. Fegan. 2004. Catch rate and catch composition of trawl fish net in the waters of the Arafura Sea. Indonesian Fisheries Resources Journal. Vol.10 (1). 2004. 9-14.

Badrudin, B. Sumiono, \& S. Nurhakim. 2004a. Hook rates and composition of bottom long line catches in the Arafura Sea. Indonesian Fisheries Resources Journal. Vol.10. (1). 2004. 1-7.

Budihardjo \& Budiman. 2003. Laju tangkap udang dan ikan demersal di Laut Arafura, Agustus 2003. Laporan Observasi. Balai Riset Perikanan Laut. (Unpublished).

Hernowo, S. 2003 Produktivitas kapal penangkap pukat udang di Laut Arafura. GAPPINDO-HPPI. Jakarta. Juli 2003. (Unpublished).

Larkin, P. A. 1982. Direction for future research in tropical multispecies fisheries. In D. Pauly \& G. I. Murphy (eds). Theory and management of tropical fisheries. Procciding of the ICLARM-CSIRO Workshop. Pp. 309-328.

Purwanto. 2003. Struktur usaha dan armada penangkapan di Laut Arafura. Direktorat Jenderal Perikanan Tangkap. 5 p. (Unpublished).

Ramm, D. C. 1995. Collaborative research and management the key to the sustainable management of groundfish resources in the Timor and Arafura Seas. Paper Presented at the Conference Neighbour at sea the Shared Interest of Australia and Indonesia in the Timor and Arafura Seas. Darwin, November 1995. (Unpublished)

Sumiono, B., T. S. Murtoyo, Y. Suselisa, \& M. Rijal. 2001. Survei laju tangkap dan kepadatan stok udang dan ikan demersal di Laut Arafura (bulan September sampai dengan Oktober 2001). Direktorat Jenderal Perikanan Tangkap. Departemen Kelautan dan Perikanan. Jakarta. (Unpublished).

Widodo. 1997. Laporan survei sumber daya perikanan demersal dengan KM. Bawal Putih II di perairan Kawasan Timur Indonesia (Nopember 1995 sampai dengan April 1996). BPPI Semarang. (Unpublished). 
Estimated Unrecorded Catch Related to the Number of Licensed .... in the Arafura Sea (Badrudin et al.)

Appendix 1. Number of licensed fishing vessel operated in the Arafura Sea (May 22, 2007) Sources: Anonymous (2007)

\begin{tabular}{|c|c|c|c|c|c|c|}
\hline \multirow{2}{*}{ Fishing Gear } & \multicolumn{5}{|c|}{ Range GT } & \multirow{2}{*}{ Total } \\
\hline & $<50$ & $51-100$ & $101-200$ & 201-400 & $>400$ & \\
\hline Bouke Ami & 9 & 18 & 9 & 2 & & 38 \\
\hline Traps & 8 & 3 & & & & 11 \\
\hline Pole and Line & 5 & 23 & & & & 28 \\
\hline Bottom Gill-net & 2 & 1 & & & & 3 \\
\hline Oceanic Gill net & 32 & 41 & 66 & 73 & 19 & 231 \\
\hline Coastal Gill & 41 & 27 & 4 & & & 72 \\
\hline Squid Jigger & 4 & 12 & 52 & 4 & 2 & 74 \\
\hline Bottom Long line & 117 & 30 & 6 & 4 & & 157 \\
\hline Fish net & & 3 & 167 & 359 & 119 & 648 \\
\hline Shrimp net & 2 & 123 & 165 & 20 & 9 & 319 \\
\hline Purse Seine (small pelagics) & 2 & 1 & 2 & & & 5 \\
\hline Total & 223 & 282 & 471 & 462 & 149 & 1,587 \\
\hline
\end{tabular}


